\title{
Markers of inflammation and fibrinolysis in canine lymphoma
}

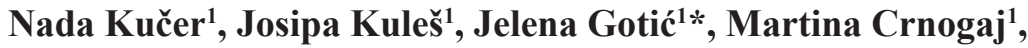 \\ Vladimir Mrljak ${ }^{1}$, and Renata Barić Rafaj ${ }^{2}$
}

${ }^{1}$ Clinic for Internal Diseases, Faculty of Veterinary Medicine, University of Zagreb, Zagreb, Croatia

${ }^{2}$ Department of Chemistry and Biochemistry, Faculty of Veterinary Medicine, University of Zagreb,

Zagreb, Croatia

\begin{abstract}
KUČER, N., J. KULEŠ, J. GOTIĆ, M. CRNOGAJ, V. MRLJAK, R. BARIĆ RAFAJ: Markers of inflammation and fibrinolysis in canine lymphoma. Vet. arhiv 88, 787-806, 2018.
\end{abstract}

\section{ABSTRACT}

Canine lymphoma is one of the most common haematological neoplasms. Results of a numerous studies indicate the important role of chronic inflammation in the development of cancer. The aim of this study was to determine the concentrations of novel inflammatory biomarkers in canine lymphoma. Fifteen dogs with lymphoma and 15 healthy dogs (control group) participated in this study. The plasma levels of high sensitivity C reactive protein (hs CRP), interleukin-6 (IL-6), high mobility group box-1 (HMGB-1), soluble intercellular adhesive molecule -1 (sICAM-1), plasminogen activator inhibitor -1 (PAI-1) and soluble urokinase receptor of plasminogen activator (suPAR) were measured using canine specific enzyme-linked immunosorbent assay (ELISA). Lactate dehydrogenase activity (LDH) was measured using a spectrophotometric method. Dogs with lymphoma had significantly increased plasma hsCRP, IL-6, HMBG-1, sICAM-1, and LDH compared with the control group. In addition, hsCRP, IL-6, HMBG-1, and suPAR concentrations and LDH activity showed a significant strong positive correlation in the lymphoma group. The data obtained support the role of cytokinemediated inflammation in canine lymphoma, and suggest the possibility that anti-inflammatory therapies might provide a supportive effect. The significant and strong positive correlation between the established (hsCRP, IL-6) and novel (HMGB-1, suPAR) inflammatory biomarkers indicate their potential usefulness in canine lymphoma diagnostics.

Key words: inflammation; fibrinolysis; lymphoma; dog

\section{Introduction}

Canine lymphoma is one of the most common haematological neoplasms and is similar to human non-Hodgkin's lymphoma (NHL) (TESKE, 1994; STERENCZAK et al., 2010). The frequency of canine lymphoma among haematopoietic malignancies is

\footnotetext{
${ }^{*}$ Corresponding author:

Jelena Gotić, PhD, Clinic for Internal Diseases, Faculty of Veterinary Medicine, University of Zagreb, Heinzelova 55, 10000 Zagreb, Croatia, Phone +385 12390 353; E-mail: jelena.gotic@vef.hr
} 
approximately $83 \%$ (VAIL et al., 2013). The symptoms of lymphoma are nonspecific and highly variable. Inflammation is a very common condition incorporated in all types of disease. It represents one of the risk factors of lymphoma development and predicts a worse treatment response and survival (EKSTRÖM et al., 2006; BENDE et al. 2009; SHARMA et al. 2009).

As is well-known, inflammation is associated with elevated plasma inflammatory markers, C-reactive protein (CRP, hsCRP) and interleukin 6 (IL-6). Novel markers such as high mobility group box-1 (HMGB-1), soluble intercellular adhesive molecule -1 (sICAM-1), plasminogen activator inhibitor -1 (PAI-1) and soluble urokinase receptor of plasminogen activator (suPAR) are still under-investigated, especially in the area of veterinary medicine.

C-reactive protein (CRP) is the most widely used acute-phase protein in dogs, as well as in humans (ISHIDA et al., 2011). In numerous studies of lymphoma, elevated CRP has been reported (HERISHANU et al., 2007; MERLO et al., 2007). CRP concentration in blood represents a prognostic factor in aggressive NHL in humans. It is also a useful biomarker in determining complete remission status after treatment with cytotoxic drugs in dogs (HERISHANU et al., 2007; NIELSEN et al., 2007).

Interleukin (IL)-6 is a pleiotropic, pro- and anti-inflammatory cytokine with a broad range of humoral and cellular immune effects, related to inflammation, host defence, and tissue injury. (RIDKER et al.; 2000 JONES et al., 2001). It is a major inducer of CRP synthesis in the liver (BAUMANN and GAULDIE, 1994). In lymphoma, IL-6 is also produced and secreted by the lymphoma cells (HERISHANU et al., 2007; BARTSCH et al., 2006). This cytokine has a dual role in the regulation of malignancy, being able both to promote and to prevent lymphoma cell development (GILBERT and HERMANN, 2012; LIN et al., 2013).

High mobility group box -1 (HMGB-1) is a highly conserved nuclear protein and a relatively novel inflammatory cytokine proposed to be a new canine marker of inflammation (BREZNICEANU et al., 2003; FIUZA et al., 2003; ISHIDA et al., 2011). It is secreted into the blood by activated monocytes and macrophages, or is released from necrotic cells (LOTZE and TRACEY, 2005; ELLERMAN et al., 2007). This protein has an intra- and extracellular role, that promotes access to transcriptional protein assemblies on specific nuclear targets. Furthermore, it functions as an extracellular molecule in inflammatory conditions and in tumor metastasis. In the circulation, HMGB-1 acts as a 'danger signal', triggers inflammation and stimulates IL-6 secretion, while high concentrations of HMBG-1 promote some tumor cell growth because of its anti-apoptotic properties (BREZNICEANU et al., 2003; IVANOV et al., 2007; ISHIDA et al., 2011; GUO et al., 2013). 
The intercellular adhesion molecule (ICAM) belongs to the group of cell adhesion molecules. It is upregulated in response to different inflammatory stimuli (FIUZA et al., 2003; ROSETTE et al., 2005; BRAKE et al., 2006). Originally described as an adhesive protein, it is now well-accepted that ICAM is able to transduce biochemical signals, and its soluble form is considered as one of the prototypic markers of inflammation (HOLLAND and OWENS, 1997; BRAKE et al., 2006). High concentrations of sICAM-1 are found in human lymphoma, and are identified as a predictor of poor outcome (TEROL et al., 2003; UCHIHARA et al., 2006; ABDELRAZIK et al., 2008). To the best of our knowledge, no data are available for canine lymphoma.

Disturbances of blood coagulation are one of the most frequent complications in human malignant lymphoma (WADA et al., 2005). Plasminogen, the plasmin enzyme system, is the primary fibrinolytic pathway responsible for vascular homeostasis. The urokinase-type plasminogen activator (uPA), when bound to its cellular receptor (uPAR), converts inactive plasminogen into active serine protease plasmin (BEVAN and MALA, 2008). The main inhibitor of plasmin generation is the plasminogen activator inhibitor (PAI-1). This binds to the uPA-uPAR complex on the cell surface, resulting in internalization of the complex (BEVAN and MALA, 2008). Changes in the fibrinolytic pathway play an important role in lymphoma cell proliferation, invasion and prognosis in humans (ZHANG et al., 2006). However, this system has scarcely been investigated in canine medicine, and so far there are no data on canine lymphoma regarding those fibrinolytic inhibitors.

LDH activity is one of the components of the International Prognostic Index in human lymphoma, and is also an important parameter in the evaluation of canine lymphoma patients (DIMOPOULOS et al., 1991; SHIPP, 1994; ZHOU et al., 2005; MAZHER et al., 2010).

There have been few or no reports concerning the novel inflammatory and fibrinolytic markers in canine medicine. The aim of this study was to determine the concentrations of some novel inflammatory markers and indicators of fibrinolytic activity (ICAM-1, HMGB-1, PAI-1 and suPAR), and their relationship to established markers. In addition, their concentrations were compared to those in healthy dogs in order to demonstrate whether these biomarkers could serve as inflammatory and fibrinolytic indicators in canine lymphoma patients.

\section{Materials and methods}

Animals. The lymphoma group (L) consisted of 15 dogs with confirmed malignant multicentric lymphoma, patients at the Clinic for Internal Diseases of the Faculty of Veterinary Medicine, University of Zagreb, Croatia. 
The dogs were aged between 2 and 13 years, of various breeds (1 Golden Retriever, 1 Beauceron, 1 Rottweiler, 1 Irish Setter, 1 Beagle, 1 Bernese Mountain Dog, 1 St. Bernard Dog, 1 Dogue de Bordeaux, 2 American Stafford Terriers, 5 mix breed) and gender (10 males and 5 females). All the dogs were evaluated by clinical examination including lymph nodes measurement, haematology analysis (CBC and blood smear examination), biochemistry analysis and urinalysis.

Lymphoma was confirmed on the basis of cytological examination by fine-needle aspiration of enlarged lymph nodes. Lymph node extirpation and histological confirmation of diagnosis were needed in 2 cases. After confirmation of diagnosis, X-ray and ultrasound were performed of the thoracic and abdominal cavity for staging purposes. The dogs were staged, sub - staged and classified according to the modificated WHO system (six dogs were classified as stage IIIb and nine dogs as stage IVb/V). The group of lymphoma patients was further divided according to LDH activity into: $\mathrm{L}_{1}$ subgroup with high $\mathrm{LDH}$ activity $(>200 \mathrm{IU} / \mathrm{L})$ and $\mathrm{L}_{2}$ subgroup with normal LDH activity $(<200 \mathrm{IU} / \mathrm{L})$.

The control group (C) consisted of 15 healthy dogs: 3 Golden Retrievers, 1 Irish Setter, 1 German Shepherd, and 10 mixed breed, 7 males and 8 females. These dogs were presented at the Clinic for routine health control. The dogs were deemed healthy based on their history, physical and laboratory data (complete blood count, serum biochemistry, and urinalysis).

The study protocol was approved by the Ethics Committee for Animal Experimentation of the Faculty of Veterinary Medicine, University of Zagreb, Croatia.

Blood analyses. lood from each dog was drawn from the cephalic vein into one EDTA vial and one plain vial, with clot activator and separation gel (Vacutainer blood collection system; Becton, Dickinson and Co., Rutherford, New Jersey 07070, USA).

Blood from the EDTA vial and sera from the plain vial (obtained by centrifugation $3000 \times \mathrm{g}$ for $10 \mathrm{~min}$ ) was promptly analysed for haematological analysis and routine biochemistry panel. Afterwards, plasma from the EDTA vial was separated from blood cells by centrifugation at $1200 \mathrm{~g}$ for $15 \mathrm{~min}$, transferred to $-80{ }^{\circ} \mathrm{C}$ within 1 hour of collection, and stored until analysis.

Red blood cell count (RBC), white blood cell count (WBC), haemoglobin concentration (HB), mean corpuscular volume (MCV), mean corpuscular haemoglobin concentration (MCHC) and red cell distribution width (RDW) were evaluated using an automatic blood cell counter, "Horiba ABX" (Diagnostics, Montpellier, France) and the original manufacturer's reagents. Blood cell morphology and WBC differential count were evaluated in Wright stained blood films.

Concentration of blood urea nitrogen (BUN), creatinine (CRE), total protein (TP), albumin (ALB), bilirubin (BILI), glucose (GLUC), alanine aminotransferase (ALT), aspartate aminotransferase (AST), gamma alkaline phosphatase (ALP), glutamyl 
transferase (GGT), lactate dehydrogenase (LDH) and calcium (Ca) were measured in sera samples using the standard spectrophotometric methods in an Olympus AU600 biochemical auto analyser (Olympus Corporation, Tokyo, Japan) and using the original reagents of the manufacturer (Olympus, Diagnostica GMBH, Hamburg, Germany).

Concentrations of hsCRP, IL-6, HMGB-1, sICAM-1, PAI-1 and suPAR were determined in plasma samples by an ELISA canine test kit (Biotang Source International, Camarillo, USA), following the manufacturer's instructions. The optical density was measured with a microplate reader at $450 \mathrm{~nm}$ (BioTek Instruments, Vermont, USA). Results are given in $\mathrm{pg} / \mathrm{mL}$ or $\mathrm{ng} / \mathrm{mL}$.

Statistics. The normality of distribution of all variables was tested by the KolmogorovSmirnov test. Differences between lymphoma and healthy dogs were tested either by the $t$ test or the Mann-Whitney U test, depending on distribution. Associations between variables were tested with Spearman's correlation coefficient. Statistical analyses were performed with computer software (Statistica for Windows, StatSoft Inc.), with the level of significance set at $\mathrm{P}<0.05$.

\section{Results}

All the measured markers were in the range of assay detection. The concentrations of the measured markers and the results of comparison of groups $\mathrm{L}$ and $\mathrm{C}$ are shown in Table 1.

Table 1. hsCRP, IL-6, HMBG-1, sICAM-1, PAI-1 and suPAR concentrations in dogs with lymphoma $(\mathrm{L}, \mathrm{n}=15)$ and control healthy $\operatorname{dogs}(\mathrm{C}, \mathrm{n}=15)$

\begin{tabular}{|l|c|c|c|c|c|c|}
\hline & Mean & Median & Min & Max & SD & P (L:C) \\
\hline hsCRP L & 4.6 & 4.7 & 2.9 & 7.8 & 1.2 & $0.015^{*}$ \\
\hline (pg/mL) C & 3.5 & 3.4 & 1.5 & 5.5 & 1.1 & \\
\hline IL-6 L & 292 & 271 & 235 & 569 & 71.2 & $0.0002^{*}$ \\
\hline (pg/mL) C & 212 & 217 & 132 & 273 & 41.2 & \\
\hline HMGB-1 L & 94.4 & 86.1 & 42.4 & 224 & 45.6 & $0.048^{*}$ \\
\hline (pg/mL) C & 71.3 & 74.0 & 40.9 & 93.5 & 14.1 & \\
\hline sICAM-1 L & 389 & 403 & 310 & 485 & 51.0 & $0.0001^{*}$ \\
\hline (pg/mL) C & 307 & 321 & 190 & 370 & 50.6 & \\
\hline PAI-1 L & 72.5 & 64.2 & 38.6 & 172 & 38.3 & 0.618 \\
\hline (pg/mL) C & 68.5 & 60.4 & 25.9 & 134 & 34.6 & \\
\hline suPAR L & 2499 & 2341 & 1796 & 4204 & 640 & 0.992 \\
\hline (pg/mL) C & 2501 & 2559 & 1905 & 2960 & 323 & \\
\hline LDH L & 287 & 74 & 41 & 1304 & 415 & $0.002 *$ \\
\hline (IU/L) C & 48.6 & 47.0 & 19.0 & 83.0 & 19.1 & \\
\hline
\end{tabular}

$* \mathrm{P}<0,05$ for $\mathrm{L}$ compared with $\mathrm{C}$ (L:C) 
The concentrations of plasma hsCRP, IL-6, HMGB-1, sICAM-1 and LDH activity in dogs with lymphoma (L) were significantly higher than those in the healthy controls (C). Although slightly increased in lymphoma, PAI-1 and suPAR concentrations did not differ significantly from those in the healthy population. The results of comparison according to $\mathrm{LDH}$ activity between all patients included (L group) and the $\mathrm{L}_{1}$ and $\mathrm{L}_{2}$ subgroups versus the control group are shown in Fig 1-7.

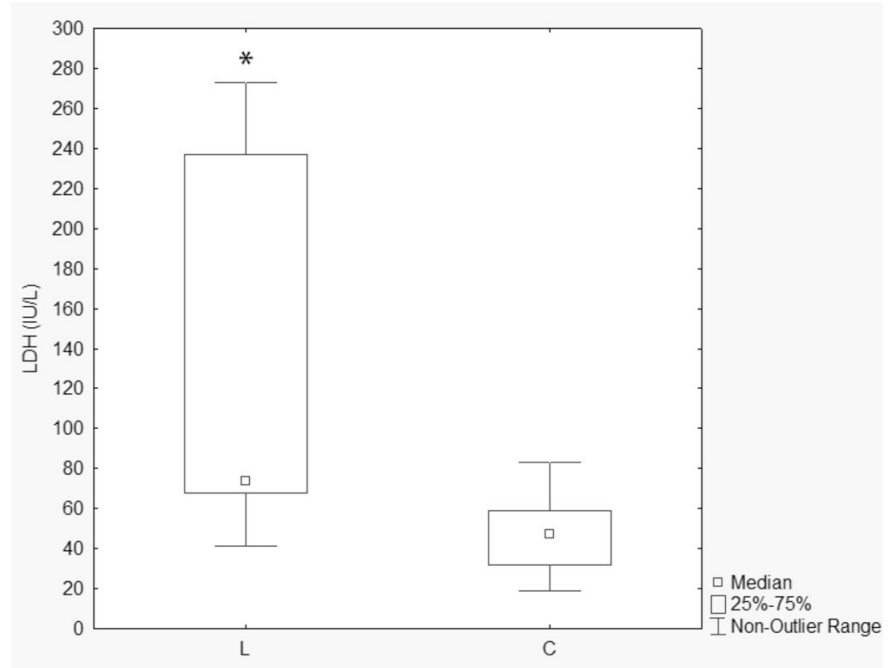

Fig. 1. LDH activity in the lymphoma group (L) and the control (C) group. *if $\mathrm{P}<0.05$ for $\mathrm{L}, \mathrm{L}_{1}$ and $\mathrm{L}_{2}$ compared with $\mathrm{C}$

Dogs with lymphoma showed significantly higher LDH activity than healthy dogs $(\mathrm{P}<0.002)$. The subgroup of patients with high LDH activity $\left(\mathrm{L}_{1}\right)$ showed significantly increased hsCRP $(\mathrm{P}<0.019)$ and HMBG-1 $(\mathrm{P}<0.003)$ compared to the control dogs, while the subgroup of patients with normal LDH activity $\left(\mathrm{L}_{2}\right)$ did not show such a difference. In both the subgroups, $\mathrm{L}_{1}$ and $\mathrm{L}_{2}$, sICAM- 1 and IL- 6 were significantly elevated. 
N. Kučer et al.: Markers of inflammation and fibrinolysis in canine lymphoma

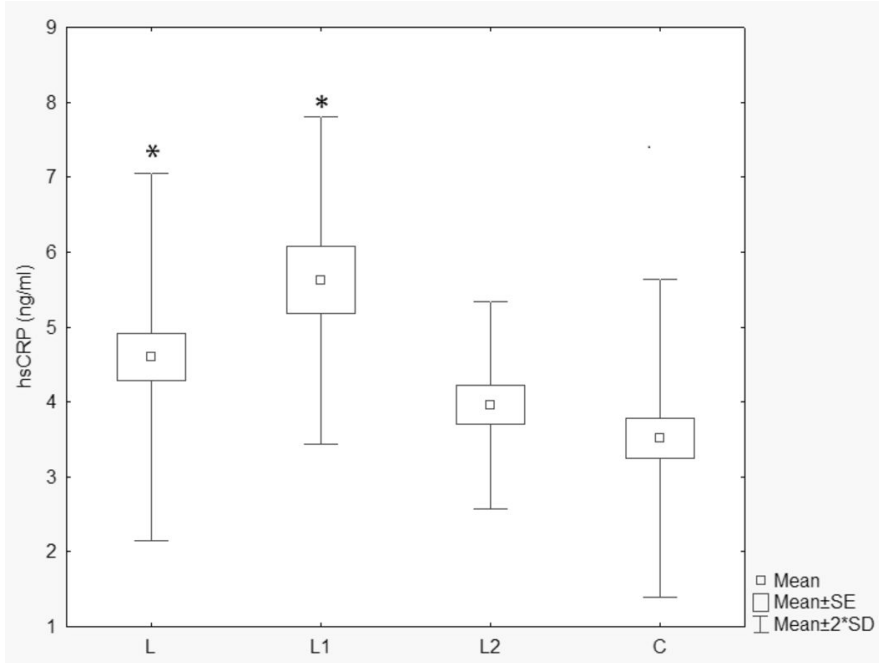

Fig. 2. hsCRP concentrations in the lymphoma group (L), high LDH activity subgroup (L1), normal LDH activity subgroup (L2) and control (C) group *if $\mathrm{P}<0.05$ for $\mathrm{L}, \mathrm{L}_{1}$ and $\mathrm{L}_{2}$ compared with $\mathrm{C}$

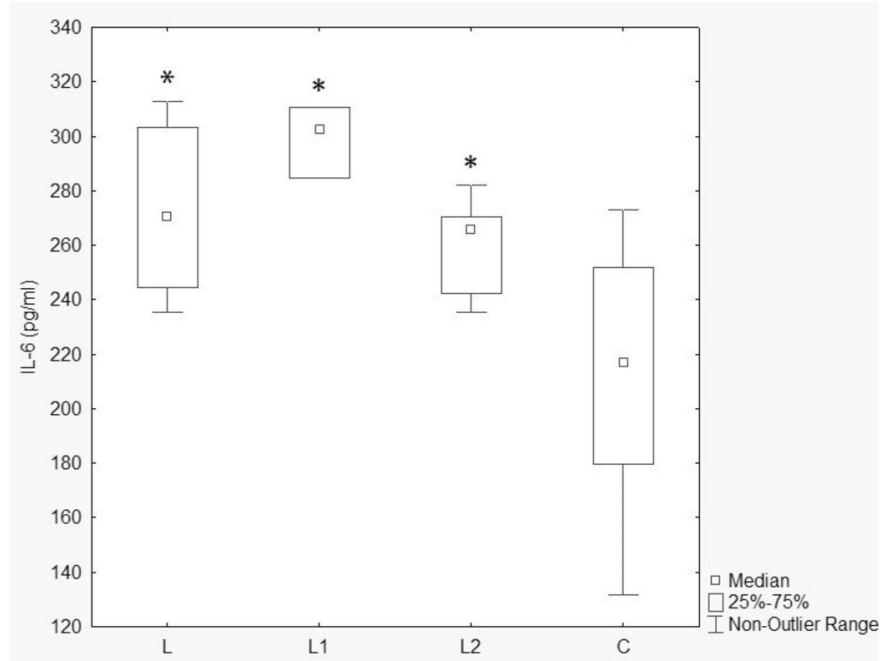

Fig. 3. IL-6 concentrations in the lymphoma group (L), high LDH activity subgroup (L1), normal LDH activity subgroup (L2) and control (C) group

*if $\mathrm{P}<0.05$ for $\mathrm{L}, \mathrm{L}_{1}$ and $\mathrm{L}_{2}$ compared with $\mathrm{C}$ 
N. Kučer et al.: Markers of inflammation and fibrinolysis in canine lymphoma

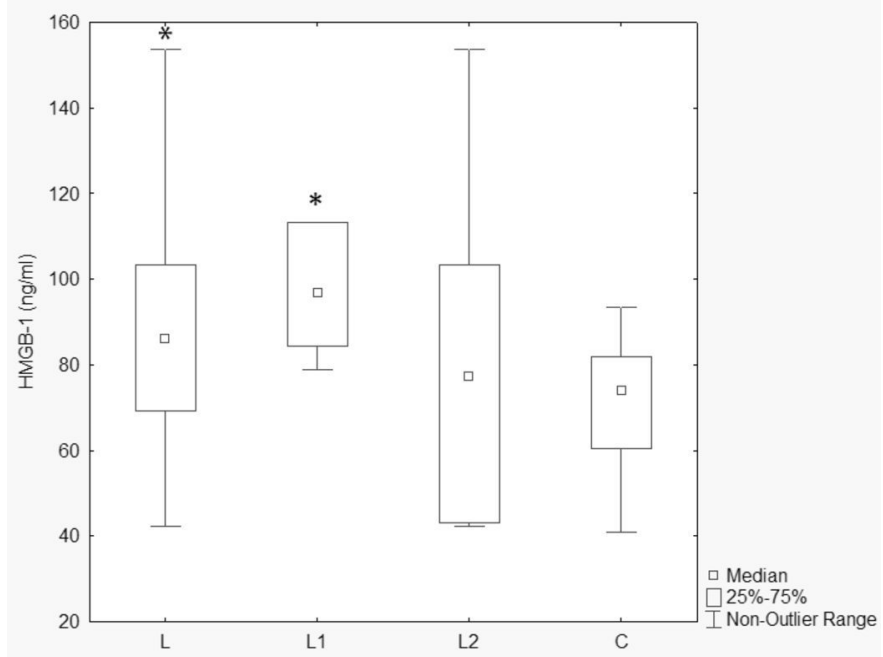

Fig. 4. HMGB-1 concentrations in the lymphoma group (L), high LDH activity subgroup (L1), normal LDH activity subgroup (L2) and control (C) group *if $\mathrm{P}<0.05$ for $\mathrm{L}, \mathrm{L}_{1}$ and $\mathrm{L}_{2}$ compared with $\mathrm{C}$

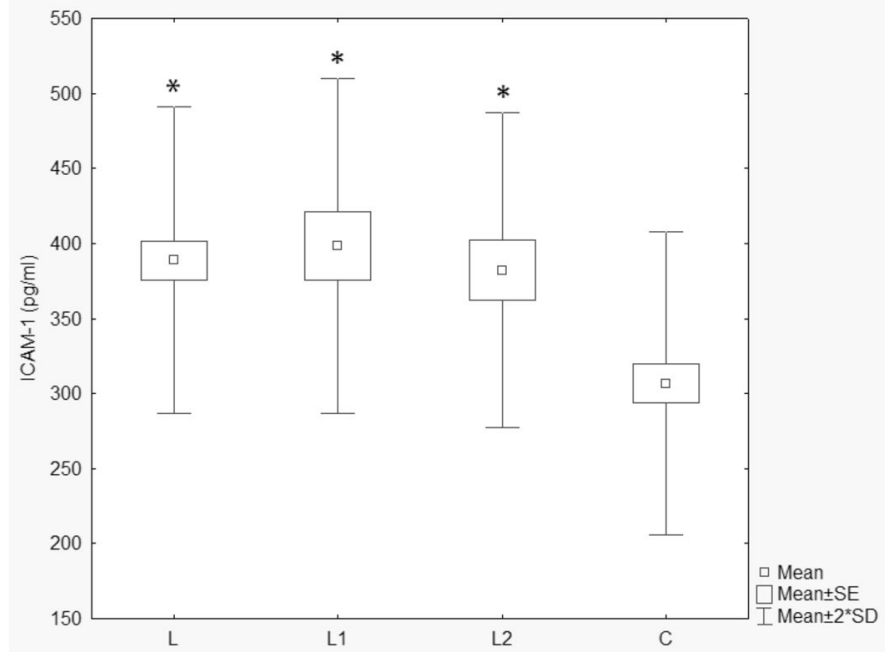

Fig. 5. sICAM concentrations in the lymphoma group (L), high LDH activity subgroup (L1), normal LDH activity subgroup (L2) and control (C) group *if $\mathrm{P}<0.05$ for $\mathrm{L}, \mathrm{L}_{1}$ and $\mathrm{L}_{2}$ compared with $\mathrm{C}$ 
N. Kučer et al.: Markers of inflammation and fibrinolysis in canine lymphoma

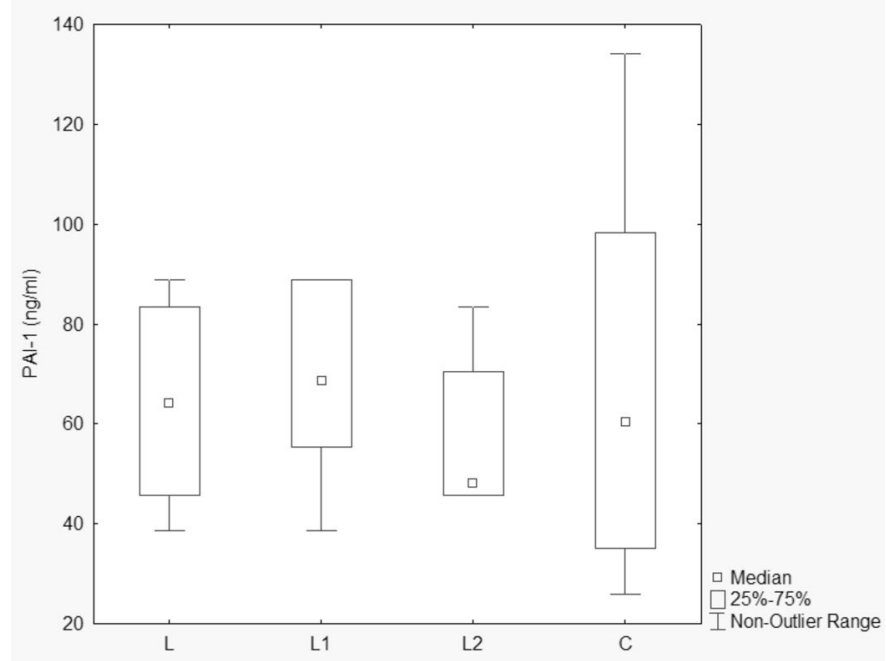

Fig. 6. PAI 1 concentrations in the lymphoma group (L), high LDH activity subgroup (L1), normal LDH activity subgroup (L2) and control (C) group

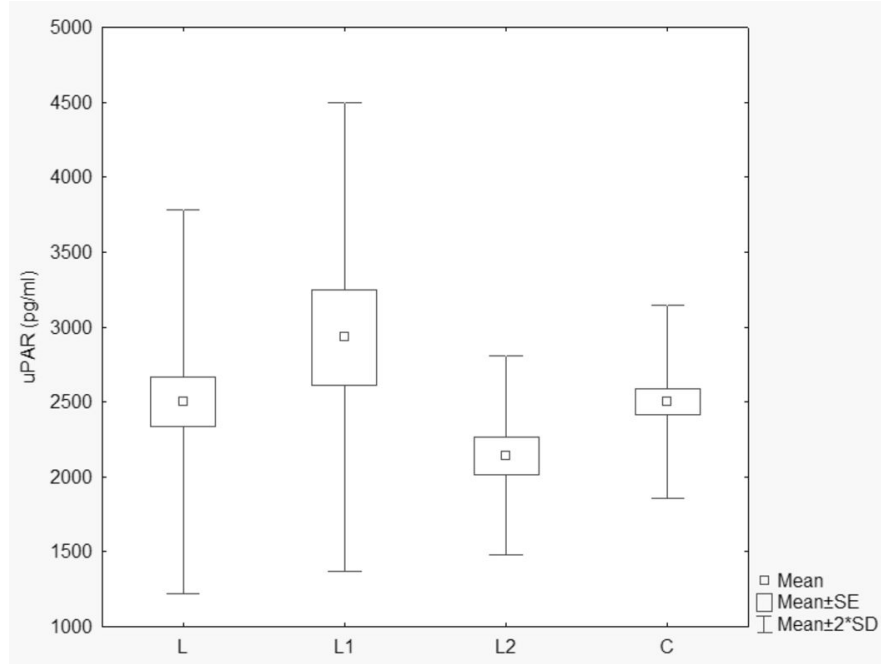

Fig. 7. suPAR concentrations in the lymphoma group (L), high LDH activity subgroup (L1), normal LDH activity subgroup (L2) and control (C) group 
N. Kučer et al.: Markers of inflammation and fibrinolysis in canine lymphoma

The correlation between markers measured is shown in Table 2 .

Table 2. Correlation between inflammatory markers (r)

\begin{tabular}{|l|c|c|c|c|c|c|c|}
\hline & hsCRP & IL-6 & HMGB-1 & ICAM-1 & PAI-1 & suPAR & LDH \\
\hline hsCRP & 1.00 & $0.82^{*}$ & $0.76^{*}$ & -0.07 & $0.65^{*}$ & $0.85^{*}$ & 0.86 \\
\hline IL-6 & $0.82^{*}$ & 1.00 & $0.81^{*}$ & 0.33 & $0.82^{*}$ & $0.75^{*}$ & $0.96^{*}$ \\
\hline HMGB-1 & $0.76^{*}$ & $0.81^{*}$ & 1.00 & 0.05 & $0.64^{*}$ & $0.76^{*}$ & $0.81^{*}$ \\
\hline sICAM-1 & -0.07 & 0.33 & 0.05 & 1.00 & 0.41 & -0.01 & 0.32 \\
\hline PAI-1 & $0.67^{*}$ & $0.82^{*}$ & $0.64^{*}$ & 0.41 & 1.00 & $0.64^{*}$ & $0.89^{*}$ \\
\hline suPAR & $0.85^{*}$ & $0.75^{*}$ & $0.76^{*}$ & -0.01 & $0.64^{*}$ & 1.00 & $0.84^{*}$ \\
\hline LDH & $0.86^{*}$ & $0.96^{*}$ & $0.81^{*}$ & 0.32 & $0.89^{*}$ & $0.84^{*}$ & 1.00 \\
\hline
\end{tabular}

*P $<0.05$

As shown in Table 2, concentrations of hsCRP, IL-6, HMGB-1, PAI-1, suPAR, and $\mathrm{LDH}$ were significantly positively correlated $(\mathrm{P}<0.05)$. There was no significant correlation between sICAM-1 and other biomarkers. A significant, medium strength, positive correlation $(\mathrm{r}=0.50-0.75)$ was detected between HMBG-1 and PAI-1, hsCRP and suPAR. A significant, strong, positive correlation $(\mathrm{r}=0.75-1.00)$ was present between all the other measured markers.

\section{Discussion}

Lymphoma is one of the most common tumours in dogs. It is a spontaneous disease, characterized by malignant lymphoid cell proliferation (VIEIRA et al., 2010, VAIL et al., 2013). Various similarities in the presentation and biology of numerous canine and human diseases, including cancer, suggest that similar mechanisms are involved in the respective pathogenic events. The clinical presentation and biological behaviour of canine lymphoma closely resemble the human disease (BEUING et al., 2008; NADELLA et al., 2008). Among the various tumour properties, inflammation is accepted as one of the common features. (MANTOVANI, 2008). Results of an increasing number of studies indicate the very important role of chronic inflammation for the development of cancer (COUSSENS and WERB, 2002).

C-reactive protein is the most sensitive acute-phase protein in dogs (CERON et al., 2005; NIELSEN et al., 2007). In the present study, the concentration of hsCRP was significantly higher in dogs with lymphoma when compared with the control group $(\mathrm{P}<0.01)$. This is in agreement with previous reports in dogs and humans. CRP concentrations were increased in dogs with neoplastic lymphatic disorders (MISCHKE and ECKERSALL, 2005; MERLO et al., 2007). CRP concentrations were higher in non-Hodgkin lymphoma in humans compared with the concentrations in healthy individuals (HERISHANU et al., 2007). In addition, many authors agreed that CRP may 
be considered as a valuable, additional prognostic marker of NHL and diffuse large B cell type lymphoma in humans (LEGOUFFE et al., 1998; CAO et al., 2012). IL-6 modulates the transcription of liver-specific genes for CRP and determines the hepatic production of this acute phase protein in inflammatory conditions (RIDKER et al., 2000; BARTSCH et al., 2006; HERISHANU et al., 2007), so we concluded that high CRP concentrations reflect elevated serum IL-6 in the investigated dogs.

In general, IL-6 plays a major role in inflammatory processes and in the development and growth of neoplasms. It was found that it is produced by lymphoblastic cell lines (EMILIE et al., 1992). Earlier studies have suggested that IL-6 is involved in the pathogenesis of human lymphoma and that this cytokine may be useful as an indicator for assessing prognosis and drug therapy (KURZROCK et al., 1993; CHOPRA et al., 2004; BARTSCH et al., 2006; MOMOI et al., 2013) Increased serum IL-6 in diffuse large B-cell human lymphomas was found to be associated with poor prognosis (BARTSCH et al., 2006). The results from our measurements showed that plasma IL-6 concentrations were significantly higher in dogs with lymphoma when compared to the healthy population of dogs $(\mathrm{P}<0.0002)$. Elevated IL-6 concentrations support the existence of a proinflammatory status in canine lymphoma, but it is not clear whether this is a one of the risk factors for lymphoma development, or the consequence of the pathological process during the disease.

HMGB-1 represents one of the novel markers of inflammation in humans as well as in veterinary medicine. Many features of tumors have been associated with alterations in HMGB-1 location, abundance or plasma concentrations (TANG et al., 2010). The lymphoma development in both species, humans and canines, is characterised by similar HMGB-related mechanisms (ROVERE-QUERINI et al., 2004; ARDOIN and PISETSKY, 2008). In our study, HMBG-1 concentrations were significantly higher in the lymphoma group when compared to healthy dogs $(\mathrm{P}<0.048)$. This high-mobility protein, also known as the damage-associated molecular pattern molecule (DAMP) has been previously described in the literature as being elevated in human lymphoma. In addition, lymph nodes in lymphoma were found to overexpress HMGB-1 mRNA (TANG et al., 2010; DEJEAN et al., 2012; MAO et al., 2012).

According to FIUZA et al. (2003) HMGB-1 is released actively from the nucleus by innate immune cells, or passively by necrotic cells. Therefore, both mechanisms could be present in dogs with lymphoma. Although the vast majority of papers describe HMGB as a proinflammatory protein, its role is not yet fully understood. Namely, a part of a protein called A box has a contrary, strong anti-inflammatory activity. Another paradoxical effect of HMBG-1 concerns its effect on tumour cells, where this protein promotes both tumour neoangiogenesis and also triggers a protective T cell response (TANG et al., 2010).

In the present study, concentrations of another novel marker, sICAM-1, were significantly higher in the lymphoma groups $(\mathrm{P}<0.0001)$, in comparison to the control 
group of dogs. These results are in agreement with previous reports for human lymphoma (UCHIHARA et al., 2006; ABDELRAZIK et al. 2008). Elevated serum ICAM concentrations in humans were found to correlate with stage, disease activity, poor response to treatment and to poor survival. Constitutively expressed ICAM-1 is a characteristic feature of lymphoma cells in lymph node biopsy samples from patients with Hodgkin type disease (UCHIHARA et a., 2006). It is suggested that at least a some of the serum ICAM-1 in childhood lymphoma patients probably originates from tumor cells (TACYILDIZ et al., 1999). Intracellular CAM has an important role in the immune response against tumor cells by mediating the $\mathrm{T}$ cell cytotoxic response. Namely, ICAM-1-stimulated antitumour immunity is able to overcome tumour-mediated immunosuppression in lymphoma (JANEWAY et al., 2001; KANWAR et al., 2003). In response to the interaction of IL- 6 with its receptor, endothelial cells up-regulate ICAM1 expression (CHEUNG et al., 2012; LIN et al., 2013). IL-6 induced expression of ICAM-1 and shedding of the soluble part of the molecule by tumour or normal cells. It may be responsible for the significant increase in ICAM-1 plasma concentrations in our examined dogs. Similar to humans, sICAM could have a role in antitumour activity in the circulation of dogs with lymphoma. The plasma concentration of sICAM-1 in dogs with lymphoma indicates an activated endothelium and might represent an additional biomarker for diagnostic use in veterinary practice.

Haemostatic disturbances with hypercoagulability are commonly detected in both human and canine cancer patients (ANDERSSON et al., 2000). Activation of the fibrinolytic system during human lymphoma progression is a well-documented clinical phenomenon (HUBER et al., 1993) so we hypothesized that fibrinolytic pathways may have a role in canine lymphoma. We measured uPA system activity by the plasma concentration of the main inhibitor of plasminogen activator, PAI-1, and its soluble receptor, suPAR. They were both increased in dogs with lymphoma, but not significantly. Probably due to the small sample size, some differences may not have been detected. The soluble form of urokinase-type plasminogen activator receptor (suPAR) is recognized as a new inflammatory marker in human medicine, while there are no data on this protein in dogs. Concentrations of suPAR in the blood have been found to correlate positively with the activation of the immune system. In human medicine, elevated concentrations of UPA and/or PAI-1 in tumour tissue extracts are associated with increased tumour aggressiveness and poor patient outcome (WADA et al., 2005). Specific blockade of plasminogen represents a promising approach for the regulation of T-cell lymphoma growth (ISHIHARA et al., 2012). The levels of plasma uPA, UPAR and PAI-1 were found to be significantly higher in humans with lymphoma than in a control group (ZHANG et al., 2006). In contrast, investigating molecular markers of coagulation and fibrinolysis in patients with malignant diseases, ZHOU et al. (2008) found that PAI-1 concentrations were not significantly higher in lymphoma patients than in a control group. Chromosomal 
translocations in leukemia and lymphoma cells did not result in elevated expression of PAI-1 and uPAR, suggesting that the uPA system was not altered in these cells. Instead of PAI-1, the authors found highly increased expression of the second isoform of PAI, PAI-2, in cells with translocations (KASYAPA et al., 2006). Inhibitors and receptors of plasminogen activator as part of the fibrinolytic pathways may have a role in canine lymphoma, but this still needs to be confirmed in a larger number of animals.

Serum LDH activity is a useful prognostic marker in haematological malignancies and a strong predictor of disease progression and survival rate in human Hodgkin's lymphoma (DIMOPOULOS et al., 1991; SHIPP et al., 1994; ZHOU et al., 2005; MAZHER et al., 2010). In patients with NHL, LDH activity is one of the components of the International Prognostic Index. Dogs with lymphoma showed significantly higher LDH activity than healthy dogs $(\mathrm{P}<0.002)$. LDH activity is higher when lymphocytes are dividing or when cells are distressed or damaged (MAZHER et al., 2010). Taking these features of LDH together, we divided lymphoma dogs into two subgroups: one with high LDH activity $\left(\mathrm{L}_{1}\right)$ and the other with normal LDH activity $\left(\mathrm{L}_{2}\right)$. The group of lymphoma dogs with high LDH activity showed significantly increased hsCRP $(\mathrm{P}<0.019)$ and HMBG-1 $(\mathrm{P}<0.003)$ compared to the control dogs, while lymphoma dogs with normal LDH activity did not show such a difference. sICAM- 1 and IL- 6 were significantly elevated in the both subgroups compared with healthy controls, so we may conclude that elevated LDH activity may be connected to a stronger inflammatory process. Concentrations of hsCRP, IL-6, HMBG-1, suPAR and LDH activity showed significant, strong $(\mathrm{P}<0.05, \mathrm{r}>0.75)$ and positive correlations in the lymphoma group, indicating the possible usefulness of the novel biomarkers of inflammation proposed in the diagnosis of the inflammatory state in canine medicine. The correlation between IL- 6 concentration and LDH activity was remarkably high (0.96), so it would be useful to investigate, in a greater number of animals, whether this enzyme could be an indicator of inflammatory status in canine lymphoma.

\section{Conclusion}

Data obtained in this study support the role of cytokine-mediated inflammation in canine lymphoma and the possibility that anti-inflammatory therapies might provide a supportive effect. However, the reverse causality of lymphoma and inflammation cannot be excluded, meaning that inflammation, as a risk factor, may in fact be causing the increase in lymphoma incidence. Nevertheless, the strong positive correlation between the established (CRP, IL-6) and novel (HMGB-1, suPAR) inflammatory biomarkers suggest their potential in canine diagnostics. Whether concentrations of the investigated biomarkers can be used to assess the invasive potential and prognosis in dogs with lymphoma, as is the case in humans, has to be investigated in further studies. 
N. Kučer et al.: Markers of inflammation and fibrinolysis in canine lymphoma

\section{Ethics approval}

The study was approved by the Ethics Committee of the University of Zagreb, Faculty of Veterinary Medicine (protocol number 640-01/12-17/22).

\section{Conflicts of interest}

The authors declare that they have no competing interests.

\section{Funding}

This research was carried out at laboratories of Faculty of Veterinary Medicine, University of Zagreb and supported financially by The Fund for Development of the University of Zagreb, and partly by the FP7 ERA Chair project 'VetMedZg"' (Grant Agreement No. 621394).

\section{References}

ABDELRAZIK, N., M. FOUDA, M. H. EL-DEEN ZAGHLOUL, D. ABBAS (2008): Serum level of intercellular adhesion molecule-1 in children with malignant lymphoma. Med. Princ. Pract. $17,233-238$.

DOI: $10.1159 / 000117798$

ANDERSSON, U., H. WANG, K. PALMBLAD, A. C. AVEBERGER, O. BLOOM (2000): High mobility group 1 protein (HMG-1) stimulates proinflammatory cytokine synthesis in human monocytes. J. Exp. Med. 192, 565-570.

DOI: $10.1084 /$ jem.192.4.565

ARDOIN, S. P., D. S. PISETSKY (2008): The role of cell death in the pathogenesis of autoimmune disease: HMGB1 and microparticles as intercellular mediators of inflammation. Mod. Rheumatol. 18, 319-326.

DOI: $10.3109 / \mathrm{s} 10165-008-0054-\mathrm{Z}$

BARTSCH, R., S. WOEHRER, M. RADERER, M. HEJNA (2006): Serum interleukin-6 levels in patients with gastric MALT lymphoma compared to gastric and pancreatic cancer. Anticancer Res. 26, 3187-3190.

BAUMANN, H., J. GAULDIE (1994): The acute phase response. Immunol. Today 15, 74-80.

DOI: 10.1016/0167-5699(94)90137-6

BENDE, R. J., F. VAN MALDEGEM, C. J. M. VAN NOESEL (2009): Chronic inflammatory disease, lymphoid tissue neogenesis and extranodal marginal zone B-cell lymphomas. Haematologica 94, 1109-1123.

DOI: 10.3324 /haematol.2009.005983

BEUING, C., J. T. SOLLER, M. MUTH, S. WAGNER, G. DOLF, C. SCHELLING, A. RICHTER, S. WILLENBROCK, N. REIMANN-BERG, S. WINKLER, I. NOLTE, J. BULLERDIEK, H. M. ESCOBAR (2008): Genomic characterisation, chromosomal assignment and in vivo localisation of the canine high mobility group A1 (HMGA1) gene. BMC Genet. 9:49.

DOI: $10.1186 / 1471-2156-9-49$ 
N. Kučer et al.: Markers of inflammation and fibrinolysis in canine lymphoma

BEVAN, P., C. MALA (2008): The role of uPA and uPA inhibitors in breast cancer. Breast Care 3, $1-2$.

DOI: $10.1159 / 000151735$

BRAKE, D. K., O. B SMITH., H. MERSMANN, C. W. SMITH, R. L. ROBKER (2006): ICAM1 expression in adipose tissue: effects of diet-induced obesity in mice. Am. J. Physiol. 291, 1232-1239.

DOI: 10.1152/ajpcell.00008.2006 Cell Physiol.

BREZNICEANU, M. L., K. VÖLP, S. BÖSSER, C. SOLBACH, P. LICHTER, S. JOOS, M. ZÖRNIG (2003): HMGB1 inhibits cell death in yeast and mammalian cells and is abundantly expressed in human breast carcinoma. FASEB J. 17(10), 1295-1297.

DOI: 10.1096/fj.02-0621fje

CAO, Y., Y. SHI, J. CHEN, Y. TAN, Y. CAI, H. LUO, M. QIU, X. CAI, Y. JIN, Y. SUN, W. JIANG (2012): C-reactive protein as an important prognostic variable in patients with diffuse large B cell lymphoma. Tumor Biol. 33, 1039-1044.

DOI: $10.1007 / \mathrm{s} 13277-012-0337-\mathrm{Z}$

CERON, J. J., P. D. ECKERSALL, S. MARTYNEZ-SUBIELA (2005): Acute phase proteins in dogs and cats: current knowledge and future perspectives. Vet. Clin. Pathol. 34, 85-99.

DOI: 10.1111/j.1939-165X.2005.tb00019.x

CHEUNG W. Y., C. A. SIMMONS, L. YOU (2012): Osteocyte apoptosis regulates osteoclast precursor adhesion via osteocytic IL-6 secretion and endothelial ICAM-1 expression. Bone 50, 104-110.

DOI: $10.1016 /$ j.bone.2011.09.052

CHOPRA, G. S., P. G. CHITALKAR, M. P. JAIPRAKASH (2004): Cytokines: as useful prognostic markers in lymphoma cases. Med. J. Armed Forces India 60, 45-49.

DOI: $10.1016 / \mathrm{S} 0377-1237(04) 80158-8$

COUSSENS, L. M., Z. WERB (2002): Inflammation and cancer. Nature 420, 860-867.

DOI: 10.1038 /nature01322

DEJEAN, E., M. FOISSEAU, F. LAGARRIGUE, L. LAMANT, N. PRADE, A. MARFAK, G. DELSOL, S. GIURIATO, F. GAITS-IACOVONI, F. MEGGETTO (2012): ALK+ALCLs induce cutaneous, HMGB-1dependent IL-8/CXCL8 production by keratinocytes through NFB activation. Blood 119, 4698-4707.

DOI: 10.1182/blood-2011-10-386011

DimOPOUlos, M. A., B. BARLOGIE, T. L. SMITH, R. ALEXANIAN (1991): High serum lactate dehydrogenase level as a marker for drug resistance and short survival in multiple myeloma. Ann. Intern. Med. 115, 931-935.

DOI: $10.7326 / 0003-4819-115-12-931$

Vet. arhiv 88 (6), 787-806, 2018 
N. Kučer et al.: Markers of inflammation and fibrinolysis in canine lymphoma

EKSTRÖM, S. K., E. BAECKLUND, J. ASKLING (2006): Malignant lymphomas in autoimmunity and inflammation: a review of risks, risk factors, and lymphoma characteristics. Cancer Epidemiol. Biomark. Prev. 15, 2069-2077.

DOI: 10.1158/1055-9965.EPI-06-0300

ELLERMAN, J. E., C. K. BROWN, M. DE VERA, H. J. ZEH, T. BILLIAR, A. RRUBARTELLI, M. T. LOTZE (2007): Masquerader: high mobility group box-1 and cancer. Clin. Cancer Res. $13,2836-2848$

DOI: $10.1158 / 1078-0432 . C C R-06-1953$

EMILIE, D., J. COUMBARAS, M. RAPHAEL, O DEVERGNE, H .J. DELECLUSE, C. GISSELBRECHT, J. F. MICHIELS, J. VAN DAMME, T. TAGA, T. KISHIMOTO (1992): Interleukin-6 production in high-grade B lymphomas: correlation with the presence of malignant immunoblasts in acquired immunodeficiency syndrome and in human immunodeficiency virus-seronegative patients. Blood 80, 498-504.

FIUZA, C., M. BUSTIN, S. TALWAR, M. TROPEA, E. GERSTENBERGER, J. H. SHELHAMER, A. F. SUFFREDINI (2003): Inflammation-promoting activity of HMGB1 on human microvascular endothelial cells. Blood 101, 2652-2660.

DOI: 10.1182/blood-2002-05-1300

GILBERT, L. A., M. T. HERMANN (2012): Context-specific roles for paracrine IL-6 in lymphomagenesis. Genes \& Dev. 26, 1758-1768.

DOI: $10.1101 / \operatorname{gad} .197590 .112$

GUO, Z. S., Z. LIU, D. L. BARTLETT, D. TANG, M. T. LOTZE (2013): Life after death: targeting high mobility group box 1 in emergent cancer therapies. Am. J. Cancer. Res. 3, 1-20.

HERISHANU, Y., C. PERRY, R. BRAUNSTEIN, U. METSER, O. GOOR, O. ROGOWSKI, S. BERLINER, A. POLLIACK, E. NAPARSTEK (2007): Early-mid treatment C-reactive protein level is a prognostic factor in aggressive non-Hodgkin's lymphoma. Eur. J. Haematol. 79, 150-154.

DOI: 10.1111/j.1600-0609.2007.00894.x

HOLLAND, J., T. OWENS (1997): Signaling through Intercellular Adhesion Molecule 1 (ICAM1) in a B Cell Lymphoma Line. J. Biol. Chem. 272, 9108-9112.

DOI: $10.1074 /$ jbc.272.14.9108

HUBER, K., J. C. KIRCHHEIMER, A. SEDLMAYER, C. BELL, D. ERMLER, B. R. BINDER (1993): Clinical value of determination of urokinase-type plasminogen activator antigen in plasma for detection of colorectal cancer: comparison with circulating tumor-associated antigens CA 19-9 and carcinoembryonic antigen. Canc. Res. 53,1788-1793.

DOI: $10.1074 /$ jbc.272.14.9108

ISHIDA, A., K. OHNO, K. FUKUSHIMA, K. NAKASHIMA, M. TAKAHASHI, Y. GOTOKOSHINO, Y. FUJINO, H. TSUJIMOTO (2011): Plasma High-Mobility Group Box 1 (HMGB1) in dogs with various diseases: comparison with C-reactive protein. J. Vet. Med. Sci. $73,1127-1132$.

DOI: $10.1292 /$ jvms.10-0540 
N. Kučer et al.: Markers of inflammation and fibrinolysis in canine lymphoma

ISHIHARA, M., C. NISHIDA, Y. TASHIRO, I. GRITLI, J. ROSENKVIST (2012): Plasmin inhibitor reduces T-cell lymphoid tumor growth by suppressing matrix metalloproteinase-9dependent CD11bţ/F4/80ţ myeloid cell recruitment. Leukemia 26, 332-339.

DOI: $10.1038 /$ leu.2011.203

IVANOV, S., A. M. DRAGOJ, X. WANG, C. DALLACOSTA, J. LOUTEN, G. MUSCO, G. SITIA, G. S. YAP, Y. WAN, C. A. BIRON, M. E. BIANCHI, H.WANG, W. M. CHU (2007): A novel role for HMGB1 in TLR9-mediated inflammatory responses to CpG-DNA. Blood 110, 19701981.

DOI: 10.1182/blood-2006-09-044776

JANEWAY, C., P. TRAVERS, M. WALPORT (2001): The development of mature lymphocytes receptor repertories: signaling through immune system receptors. In: Immunobiology: The Immune System in Health and Disease (Janeway, C., P. Travers, M. Walport, M. Shlomchik, Eds), $2^{\text {nd }}$ ed., Edinburgh, Churchill Livingstone, p. 213.

JONES, S. A., S. HORIUCHI, N. TOPLEY, N. YAMAMOTO, G. M. FULLER (2001): The soluble interleukin 6 receptor: mechanisms of production and implications in disease. FASEB J. 15, 43-58.

DOI: $10.1096 /$ fj.99-1003rev

KANWAR, J. R., BERG R. W., YANG Y., K. K. RUPINDER, L. M. CHING, X. SUN, G. W. KRISSANSEN (2003): Requirements for ICAM-1 immunogene therapy of lymphoma. Canc. Gen. Ther. 10, 468-476.

DOI: $10.1038 /$ sj.cgt.7700590

KASYAPA, C. S., P. KUNAPULI, L. HAWTHORN, J. K. COWELL (2006): Induction of the plasminogen activator inhibitor-2 in cells expressing the ZNF198/FGFR1 fusion kinase that is involved in atypical myeloproliferative disease. Blood 107, 3693-3699.

DOI: $10.1182 /$ blood-2005-04-1505

KURZROCK, R., J. REDMAN, F. CABANILLAS, D. JONES, J. ROTHBERG, M. TALPAZ (1993): Serum Interleukin 6 Levels Are elevated in lymphoma patients and correlate with survival in advanced Hodgkin's disease and with B symptoms. Canc. Res. 53, 2118-2122.

LEGouffe, E., C. RODRigueZ, M. C. PICOT, B. RiCHARD, B. KLEIN, J. F. ROSS, T. COMMES (1998): C-reactive protein serum level is a valuable and simple prognostic marker in non Hodgkin's lymphoma. Leuk. Lymphoma 31, 351-357.

DOI: $10.3109 / 10428199809059228$

LIN, Y. M., Z. L. CHANG, Y. Y. LIAO, M. C. CHOU, C. H. TANG (2013): IL-6 promotes ICAM-1 expression and cell motility in human osteosarcoma. Cancer Lett. 328, 135-143.

LOTZE, M. T., K. J. TRACEY (2005): High-mobility group box 1 protein (HMGB1): nuclear weapon in the immune arsenal. Nat. Rev. Immunol. 5, 331-342.

DOI: $10.1038 /$ nri1594

MANTOVANI, A. (2008): Cancer: inflaming metastasis. Nature 457, 36-37.

DOI: $10.1038 / 457036 \mathrm{~b}$

Vet. arhiv 88 (6), 787-806, 2018 
N. Kučer et al.: Markers of inflammation and fibrinolysis in canine lymphoma

MAO, X. Y., G. F. WANG, Z. J. CHEN, L. N. WANG, J. B. ZHANG, H. L. WANG (2012): Expression of HMGB1 and its clinical significance in T-cell lymphoma. Asian. Pac. J. Cancer Prev. 13, 5569-5571.

DOI: 10.7314/APJCP.2012.13.11.5569

MAZHER, N., Z. IQBAL, N. ASLAM, S. MAZHER (2010): Serum lactate dehydrogenase 2 isoenzyme as marker of bone marrow infiltration in non Hodgkin lymphoma. Int. J. Pathol. 8, 9-12.

MERLO, A., B. C. GAGLIANO REZENDE, M. L.FRANCHINI, D. M. NUNES SIMÕES, S. R. RICCI LUCAS (2007): C-reactive protein concentrations in dogs with multicentric lymphoma undergoing chemotherapy. J. Am.Vet. Med. Assoc. 230, 522-526.

DOI: $10.2460 /$ javma.230.4.522

MISCHKE, R., P. D. ECKERSALL (2005): Changes in C-reactive protein and haptoglobin in dogs with lymphatic neoplasia. $5^{\text {th }}$ International Colloquium on Animal Acute Phase Proteins - Dublin 2005.

MOMOI, A., M. KOJIMA, T. SAKAI, J. AJIRO, N. ISAHAI, K. NAGAI, S. AOKI (2013): IL6-positive classical Hodgkin's lymphoma co-occurring with plasma cell type of Castleman's disease: report of a case. Int. J. Hematol. 97, 275-279.

DOI: $10.1007 / \mathrm{s} 12185-013-1262-7$

NADELLA, M. V. P., W. C. KISSEBERTH, K. S. NADELLA, N. K. THUDI, D. H. THAMM, E. A. MCNIEL, A. YILMAZ, K. BORIS-LAWRIE, T. J. ROS (2008): NOD/SCID mouse model of canine T-cell lymphoma with humoral hypercalcaemia of malignancy: cytokine gene expression profiling and in vivo bioluminescent imaging. Vet. Comp. Oncol. 6, 39-54.

DOI: 10.1111/j.1476-5829.2007.00139.x

NIELSEN, L., N. TOFT, P. D. ECKERSALL, D. J. MELlOR, J. S. MORRIS (2007): Serum C-Reactive protein concentration as an indicator of remission status in dogs with multicentric lymphoma. J. Vet. Intern. Med. 21, 1231-1236.

DOI: 10.1111/j.1939-1676.2007.tb01943.x

RIDKER, P. M., N. RIFAI, M. J. STAMPFER, C. H. HENNEKENS (2000): Plasma concentration of interleukin- 6 and the risk of future myocardial infarction among apparently healthy men. Circulation 101, 1767-1772.

DOI: 10.1161/01.CIR.101.15.1767

Rosette, C., R .B. ROTh, P. OETH, A. BRAUn, S. KAMMERER, J. EKBLOM, M. F. DENISSENKO (2005): Role of ICAM1 in invasion of human breast cancer cells. Carcinogenesis 26, 943-950.

DOI: $10.1093 /$ carcin/bgi070

ROVERE-QUERINI, P., A. CAPOBIANCO, P. SCAFFIDI, B. VALENTINIS, F. CATALANOTTI, M. GIAZZON, I. E. DUMITRIU, S. MÜLLER, M. IANNACONE, C. TRAVERSARI, M. E. BIANCHI, A. A. MANFREDI (2004): HMGB1 is an endogenous immune adjuvant released by necrotic cells. EMBO rep. 5, 825-830.

DOI: 10.1038/sj.embor.7400205 
N. Kučer et al.: Markers of inflammation and fibrinolysis in canine lymphoma

SHARMA, R., D. CUNNINGHAM, P. SMITH, G. ROBERTSON, O. DENT, S. J. CLARKE (2009): Inflammatory (B) symptoms are independent predictors of myelosuppression from chemotherapy in Non-Hodgkin Lymphoma (NHL) patients - analysis of data from a British National Lymphoma Investigation phase III trial comparing CHOP to PMitCEBO. BMC Cancer 153 .

DOI: $10.1186 / 1471-2407-9-153$

SHIPP, M. A.(1994): Prognostic factors in aggressive non-Hodgkin's lymphoma: who has "highrisk" disease? Blood 83, 1165-1173.

STERENCZAK, K. A, A. E. JOETZKE, S. WILlENBROCK, N. EBERLE, S. LANGE, C. JUNGHANSS, I. NOLTE, J. BULLERDIEK, D. SIMON, H. MURUA ESCOBAR (2010): High-mobility group B1 (HMGB1) and receptor for advanced glycation end-products (RAGE) expression in canine lymphoma. Anticancer Res. 30, 5043-5048.

TACYILDIZ N, G YAVUZ, S GOZDASOGLU, E. UNAL, U. ERTEM, F. DURU, A. IKINCIOGULLARI, E. BABACAN, A. ENSARI, A. OKCUOGLU-CAVDAR (1999): Serum levels and differential expression of intercellular adhesion molecule-1 in childhood leukemia and malignant lymphoma: prognostic Importance and relationship with survival. Pediatr. Hematol. Oncol.16, 149-158.

DOI: $10.1080 / 088800199277470$

TANG, D., R. KANG, H. J. ZEH III, M. T. LOTZE (2010): High-mobility Group Box 1 [HMGB1] and cancer. Biochim. Biophys. Act. 1799, 131-140.

DOI: 10.1016/j.bbagrm.2009.11.014

TEROL, M. J., M. TORMO1, J. A. MARTINEZ-CLIMENT, I. MARUGAN, I. BENET, A. FERRANDEZ, A. TERUEL, R. FERRER, J. GARCIA CONDE (2003): Soluble intercellular adhesion molecule-1 (s-ICAM-1/s-CD54) in diffuse large B-cell lymphoma: association with clinical characteristics and outcome. Ann. Oncol. 14, 467-474.

DOI: $10.1093 /$ annonc/mdg057

TESKE, E. (1994): Canine malignant lymphoma: a review and comparison with human nonHodgkin's lymphoma. Vet. Quart. 16, 209-219.

DOI: 10.1080/01652176.1994.9694451

UCHIHARA, J. N., T. MATSUDA, T. OKUDAIRA, N. MORI (2006): Transactivation of the ICAM-1 gene by CD30 in Hodgkin's lymphoma. Int. J. Canc. 118, 1098-1107.

DOI: $10.1002 /$ ijc. 21427

VAIL D. M., M. E. PINKERTON, K. M. YOUNG (2013): Canine Limphoma and Leukemias; In: Withrow and MacEwen's Small Animal Clinical Oncology. $5^{\text {th }}$ ed. St. Louis: Saunders Elsevier, pp. 608-638.

DOI: $10.1002 /$ ijc. 21427

VIEIRA, M. C., F. E. D. COLETA, A. V. GODOY, A. E. SANTANA (2010): Acute phase proteins in canine lymphoma during antineoplastic chemotherapy. Braz. J. Vet. Pathol. 3, 86-92. 
N. Kučer et al.: Markers of inflammation and fibrinolysis in canine lymphoma

WADA, H., T. SASE, M. YAMAGUCHI (2005): Hypercoagulant states in malignant lymphoma. Exo. Oncol. 27, 179-185.

ZHANG, Q., S. HOU, X. LI, J. HE, L. WANG (2006): The relationship between urokinase plasminogen activator system and non-Hodgkin lymphoma. J. Leuk. Lymphoma 15, 356-358.

ZHOU, S.Y., Y. K. SHI, X. H. HE, P. ZHANG, M. DONG, D. Z. HUANG, J. L. YANG, C. G. ZHANG, P. LIU, S. YANG, F. Y. FENG (2005): Treatment effect of DICE regimen on patients with relapsed or refactory intermediate and highgrade non-Hodgkin's lymphoma. A. Zheng $24,465-469$.

ZHOU, H., F. LIU, S. YAN (2008): Study of molecular markers of coagulation and fibrinolysis in patients with maligant diseases. Chin. J. Health. Lab. Technol. 20, 211-217.

Received: 25 September 2018

Accepted: 14 December 2018

KUČER, N., J. KULEŠ, J. GOTIĆ, M. CRNOGAJ, V. MRLJAK, R. BARIĆ RAFAJ: Pokazatelji upale i fibrinolize u pasa oboljelih od limfoma. Vet. arhiv 88, 787-806, 2018.

\section{SAŽETAK}

Limfom je najčešći hematopoetski tumor u pasa. Brojna istraživanja potvrđuju važnu ulogu upale, napose kronične, u razvoju ove, ali i drugih malignih bolesti te je cilj ovoga rada bio odrediti koncentraciju novijih markera upale u plazmi pasa oboljelih od limfoma. U istraživanje je bilo uključeno 15 oboljelih pasa i 15 pasa koji su činili kontrolnu skupinu. Određena je koncentracija C-reaktivnog proteina (hsCRP), interleukina 6 (IL-6), proteina visoke pokretljivosti grupe 1 (HMGB-1), solubilne intercelularne adhezijske molekule 1 (sICAM-1), inhibitora aktivatora plazminogena 1 (PAI-1), solubilnog receptora urokinaznog aktivatora plazminogena (suPAR) i aktivnosti laktat-dehidrogenaze (LDH). Pretrage za sve navedene pokazatelje učinjene su imunoenzimnim testom, osim laktat-dehidrogenaze čija je aktivnost određena spektrofotometrijski. Utvrđeno je da psi oboljeli od limfoma imaju statistički značajno povišenu koncentraciju hsCRP-a, IL-6, HMBG1, sICAM-1 te LDH u plazmi u odnosu na kontrolnu skupinu. Rezultati potvrđuju ulogu upale posredovane citokinima u patogenezi limfoma u pasa, a to zatim upućuje na mogućnost uključivanja protuupalnih lijekova u terapijske protokole kod ove bolesti. Nadalje, jaka pozitivna korelacija između CRP-a i IL-6 te HMGB-1 i suPAR kao novih pokazatelja upućuje na potencijalnu mogućnost njihova korištenja u dijagnostičke svrhe.

Ključne riječi: upala; fibrinoliza; limfom; pas 